\title{
Sifat Mekanik Gigi Tiruan Akrilik dengan Penguat Serat Gelas
}

\author{
Zuriah Sitorus, Awan Maghfirah, Yosephin Romania dan Syahrul Humaidi \\ Departemen Fisika, FMIPA, Universitas Sumatera Utara, Medan \\ Email: humaidi2009@gmail.com
}

Received 23-07-2014, Revised 02-09-2014 , Accepted 10-10-2014, Published 31-10-2014

\begin{abstract}
The research is aimed to investigate the possibility of acrylic-reinforced glass fibre as a denture. Short glass fibre was made by variation of $4 \mathrm{~mm}, 6 \mathrm{~mm}$ and $8 \mathrm{~mm}$. The results showed a good adhesion between glass fibre and acrylic resin with an optimum composition of the denture (acrylic: oil : glass fibre $=10 \mathrm{gr}: 4.5 \mathrm{~mL}: 0.13 \mathrm{gr}$ ) was achieved. The density test was conducted by using Archimedes' method, whereas compressive strength and tensile strength by using Universal Testing Machine (UTM). The results showed that glass fibre can be used to enhance the mechanical properties of acrylic resin. The optimum composition was achieved when $6 \mathrm{~mm}$ fibre had been added-in with a density of $1.2256 \mathrm{gr} / \mathrm{cm}^{3}$. A compressive strength of $76.623 \mathrm{MPa}$ and a tensile strength of $71.207 \mathrm{MPa}$ were recorded, these values can be applied as a denture.
\end{abstract}

Keywords : glass fibre, acrylic resin, density, mechanical properties

\section{ABSTRAK}

Penelitian ini bertujuan melihat potensi serat gelas sebagai penguat akrilik pada gigi tiruan manusia. Serat gelas pendek digunakan dengan variasi $4 \mathrm{~mm}, 6 \mathrm{~mm}$ dan $8 \mathrm{~mm}$. Hasil penelitian menunjukkan serat kaca dapat beradhesi dengan matriks polimer/resin akrilik. Pengujian yang telah dilakukan mendapatkan perbandingan komposisi optimum perbandingan komposisi resin akrilik, minyak gigi dan serat kaca adalah $10 \mathrm{gr}: 4,5 \mathrm{~mL}: 0,13$ gr.. Pengujian densitas dilakukan dengan metode Archimedes, sementara pengujian mekanik meliputi kuat tarik dan kuat tekan menggunakan mesin Universal Testing Machine (UTM). Hasil pengujian menunjukkan bahwa serat gelas dapat memperbaiki sifat mekanik resin akrilik. Komposisi optimum diperoleh untuk panjang serat $6 \mathrm{~mm}$ dengan nilai densitas $1,2256 \mathrm{gr} / \mathrm{cm}^{3}$. Hasil pengujian untuk kekuatan tekan 76,623 MPa dan nilai kekuatan tarik 71,207 MPa, yang merupakan besaran yang sesuai digunakan untuk gigi tiruan.

Kata kunci : serat gelas, resin akrilik, densitas, sifat mekanik 


\section{PENDAHULUAN}

Jika makanan adalah kebutuhan primer manusia, maka segala sesuatu berkaitan dengan makanan juga merupakan kebutan primer. Proses makanan menjadi energi aktivitas manusia tentu melibatkan alat-alat pencernaan makanan yang sangat kompleks. Salah satu alat pencernaan manusia adalah gigi, yang dimiliki oleh manusia sejak lahir. Namun seiring dengan penambahan usia perkembangannya, tidak semua gigi berfungsi dalam waktu lama. Penggantian gigi asli dengan gigi tiruan adalah hal yang lumrah bagi manusia. Gigi tiruan lengkap dapat didefinisikan sebagai protesa gigi lepasan yang dimaksudkan untuk menggantikan permukaan pengunyahan dan struktur-struktur yang menyertainya dari suatu lengkung gigi rahang atas dan rahang bawah. Protesa tersebut terdiri dari gigi-gigi tiruan yang dilekatkan pada basis protesa. Basis protesa memperoleh dukungan melalui kontak yang erat dengan jaringan mulut dibawahnya. Meskipun basis protesa individual dapat dibuat dari logam atau campuran logam, kebanyakan basis protesa dibuat menggunakan polimer. Polimer tersebut dipilih berdasarkan keberadaannya, kestabilan dimensi, karakteristik penanganan, warna, dan kekompakan dengan jaringan mulut. Selain itu harus dapat juga memperbaiki ketepatan dan kestabilan dimensi dari protesa gigi lengkap ${ }^{[1]}$. Resin akrilik biasanya digunakan sebagai bahan dasar pembuatan gigi tiruan, karena bersifat biocompatibel, flexibel, dan bahannya mudah diperoleh dan harganya murah ${ }^{[2]}$. Bagaimanapun, bahan ini masih memiliki kekurangan dalam aplikasinya diantaranya: bahan ini mudah patah dan menimbulkan pori akibat adanya penguapan monomer yang tidak bereaksi dengan polimer ${ }^{[1]}$. Kelebihan bahan ini yang utama tentu saja menyerupai gigi asli, sesuai estetika dan dapat diperkuat dengan penambahan serat $\mathrm{kaca}^{[3-6]}$. Pada penelitian ini dilakukan pembuatan gigi tiruan yang berbahan dasar resin akrilik polimerisasi panas no.3 dengan penambahan variasi serat kaca. Resin akrilik yang dipilih no.3 karena warna dari resin ini sesuai dengan warna gigi asli manusia ${ }^{[7-8]}$. Serat kaca (fiberglass) adalah serat yang dapat ditambahkan ke dalam resin akrilik untuk memperbaiki sifat fisis dan mekanis resin akrilik ${ }^{[9,11]}$. Penambahan serat kaca pada gigi tiruan ini berfungsi meningkatkan sifat fisis dan mekanisnya serta dapat beradhesi dengan matriks polimer didalam resin akrilik ${ }^{[6,11]]}$ sehingga memiliki kekuatan ikatan yang baik dengan resin akrilik. Hasil penelitian Ramadhani ${ }^{[10]}$ yang menggunakan resin akrilik polimerisasi panas yang ditambah dengan serat kaca potongan kecil dapat mempengaruhi analisa dari basis gigi tiruan tersebut sehingga dapat membuat terobosan baru dari basis gigi tiruan dalam dunia kedokteran gigi. Oleh karena itu serat kaca menjadi pilihan untuk ditambahkan ke dalam resin akrilik sebagai bahan penguat. Komposisi resin akrilik, minyak gigi dan serat kaca dibuat sedemikian rupa sehingga dengan perbandingan tertentu dapat dihasilkan protesa gigi tiruan yang paling tepat untuk mendapatkan 3 buah sampel yang sesuai dengan model induk. Ukuran panjang serat kaca yang digunakan adalah $4 \mathrm{~mm}, 6 \mathrm{~mm}$, dan $8 \mathrm{~mm}$ sebagai variable bebas dari penelitian ini. Pengujian yang dilakukan yaitu, pengujian fisis yang terdiri dari pengujian porositas dan densitas yang gunanya untuk mengetahui apakah gigi tiruan yang dihasilkan memiliki struktur yang baik yang mencakup susunan atom yang rapat atau renggang ataupun kristal dan amorf. Pengujian mekanik yaitu, kuat tekan, kuat tarik dan kekerasan Vickers gunanya untuk mengetahui bagaimana kekuatan dari gigi tiruan tersebut. 


\section{METODE}

Pembuatan gigi tiruan dengan menggunakan metode konvensional dengan membuat model induk dari logam stainless steel dengan ukuran $80 \mathrm{~mm}$ x $10 \mathrm{~mm}$ x $4 \mathrm{~mm}$ : sebagai cetakan sampel. Kuvet besar (Smith, China) digunakan untuk menanam model induk. Sedangkan mangkuk karet dan Spatula : untuk mengaduk tepung gips. Beberapa alat yang digunakan diantaranya: Alat pengaduk resin aklirik dan wadah mengaduk resin aklirik dari porselen, Beaker glass : untuk mengukur banyaknya air yang digunakan, Neraca digital : untuk menimbang tepung gips dan resin akrilik, Tepung Putih 3 ( Resin Akrilik Polimerisasi Panas, GC,AMERICA INC), Minyak gigi ( Heat - cure acrylic) Masker, Sarung tangan, Unit kuring (Filli Manfredi, Italia) : Untuk melakukan proses kuring, Press hidraulik ( OL 57 Manfredi, Italia), Press Manual, Vibrator : untuk mengaduk tepung gips agar tercampur rata/homogeny, Plastik selopan, Oven : untuk mengeringkan sampel.

Untuk pengujian sampel menggunakan peralatan: Kawat/statif, Beaker glass, Microhardness Tester tipe MXT - 50 (Matsuzawa), Air, Kertas pasir waterproff (Global. No 300 dan 600) dan Vaselin dan Cold Mould Seal (GC,AMERICA INC)

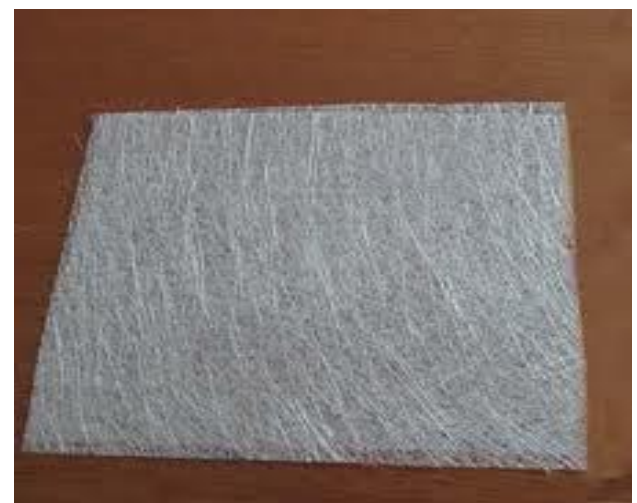

(a)

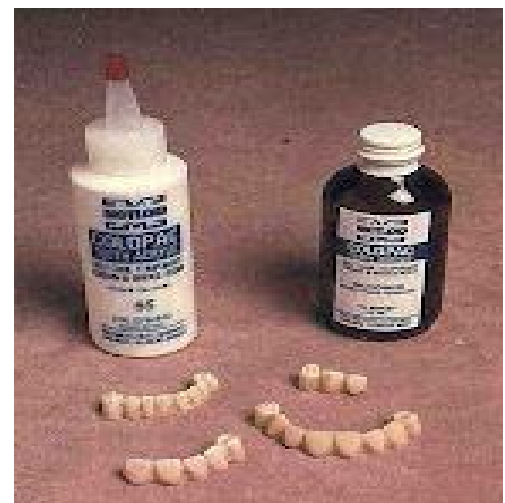

(b)

Gambar 1. (color online) Serat kaca komersial (a) dan resin akrilik berwarna gusi manusia (b)

\section{Pembuatan Mould}

Pembuatan mould dimulai dengan pencampuran Gips keras dengan air dalam mangkok karet dengan perbandingan $200 \mathrm{gr}$ : $70 \mathrm{ml}$. Kemudian adonan gips keras diaduk dengan spatula selama 15 detik, dilanjutkan dengan vibrator selama 30 detik.Selanjutnya adonan dituang ke dalam kuvet bawah yang telah disiapkan di atas vibrator. Model induk dari logam ukuran $80 \mathrm{~mm}$ x $10 \mathrm{~mm}$ x $4 \mathrm{~mm}$ dibenamkan setinggi permukaan adonan gips keras yang telah diolesi dengan vaselin, satu kuvet berisi 3 buah model induk. Setelah mongering, gips didiamkan 60 mnt. Selanjutnya permukaan gips keras diolesi vaselin dan kuvet atas disatukan dan diisi adonan gips keras dengan perbandingan 200 gram : $70 \mathrm{ml}$ air di atas vibrator. Kuvet atas ditutup dengan penutupnya, kemudian di press secara manual dan ditunggu hingga 60 menit sebelum dilepaskan press manual dan model induk dikeluarkan dari dalam kuvet. Mould disiram dengan air panas sampai bersih untuk membuang sisa vaselin dan kemudian dikeringkan. Setelah kering selanjutnya permukaan gips keras diolesi dengan could mould seal, dan dibiarkan selama 20 menit. 


\section{Proses Pembuatan Gigi}

\section{Tanpa Serat kaca $($ kontrol = komposisi 1)}

Tepung gigi dengan perbandingan $10 \mathrm{gr}: 4,5 \mathrm{~mL}$ dan minyak gigi dimasukkan ke dalam wadah porselen lalu dicampurkan adonan tersebut hingga tercampur dengan rata. Setelah adonan tercampur dengan rata, ditunggu adonan sampai mencapai fase dough sebelum dimasukkan ke dalam cetakan gipps (mould) yang telah kering. Diratakan adonan yang sudah masuk ke dalam cetakan gipps dan ditutup adonan dengan plastik selopan, kemudian kuvet atas dipasangkan lalu dipress (hidrolik) mencapai tekanan 500 psi selama 5 menit, lalu dibuka dan adonan yang berlebihan dipotong.Untuk memberikan tekanan, ditutup kembali adonan dengan kuvet atas, dan di press (hidrolik) kembali dengan tekanan 1000 psi selama 5 menit. Selanjutnya dikeluarkan kuvet dari press hidrolik, dan dimasukkan ke dalam press manual.

\section{Penambahan Serat kaca 4 mm (komposisi 2)}

Mula-mula Dipotong-potong serat kaca dengan ukuran $4 \mathrm{~mm}$. Direndam ke dalam $2 \mathrm{~mL}$ monomer selama 1 menit, lalu ditiriskan, selanjutnya dicampur ke dalam adonan tepung gigi dan minyak gigi yang telah disiapkan di wadah porselen lalu diaduk perlahan-lahan.

Setelah adonan telah mencapai fase dough kemudian dimasukkan ke dalam cetakan gigi (mould) sebelum ditutup dengan plastik selopan, kemudian kuvet atas dipasang, dan ditekan secara perlahan-lahan dengan press hidrolik mencapai tekanan 500 psi selama 5 menit, lalu dibuka. Dipotong adonan yang berlebih. Kemudian dipasang kembali kuvet atas, dan dilakukan press (hidrolik) kembali dengan tekanan 1000 psi selama 5 menit dan selanjutnya dikeluarkan kuvet dari press hidrolik, kemudian dimasukkan ke dalam press manual.

\section{Penambahan Serat kaca 6 mm dan 8 mm}

Prosedur pengisian adonan pada mould untuk panjang serat $6 \mathrm{~mm}$ dan $8 \mathrm{~mm}$ sama dengan prosedur pengisian akrilik pada komposisi 2. Pada masing-masing komposisi ini serat kaca yang digunakan adalah serat kaca ukuran panjang $6 \mathrm{~mm}$ dan $8 \mathrm{~mm}$.

\section{Kuring (Pemasakan/Perebusan)}

Mula-mula dimasukkan air ke dalam panci sebanyak 5 liter kemudian dimasukkan kuvet yang berada pada press manual sebelum dimasak diatas kompor sampai mendidih. Pada saat mendidih, dimasak selama 60 menit. Setelah 60 menit, dimatikan kompor dan ditunggu sampai dingin. Selanjutnya dikeluarkan press manual dari panci, dan direndam ke dalam air selama 48 jam.

\section{Proses Akhir}

Dikeluarkan sampel dari kuvet, lalu kelebihan akrilik dirapikan dengan bor khusus untuk menghilangkan bagian yang tajam dan dihaluskan dengan kertas pasir nomor 300 dan 600

\section{Pengujian Densitas}

Pengukuran densitas pada resin akrilik polimerisasi panas dilakukan dengan menggunakan prinsip Archimedes. 
Pengukuran densitas :

Sampel yang akan diuji, dikeringkan di dalam oven dengan suhu $100^{\circ} \mathrm{C}$ selama 1 jam kemudian ditimbang massanya dengan menggunakan neraca digital (m). Selanjutnya dimasukkan air sebanyak $15 \mathrm{ml}(\mathrm{v})$ ke dalam gelas ukur $25 \mathrm{~mL}$ dan dimasukkan sampel ke dalam gelas ukur yang telah diisi air. Kemudian diukur pertambahan volume air pada gelas ukur. Dengan mengetahui besaran-besaran tersebut, maka densitas dapat ditentukan dengan menggunakan Persamaan:

$$
\rho=\frac{m}{V}
$$

$$
\begin{gathered}
\text { dengan : } \rho=\text { densitas }\left(\mathrm{g} / \mathrm{cm}^{3}\right) \\
V=\text { volume sampel }\left(\mathrm{cm}^{3}\right)
\end{gathered}
$$

\section{Porositas (Porosity)}

Tujuan dari pengukuran porositas adalah untuk mengetahui apakah resin akrilik polimerisasi panas memiliki porositas sesuai dengan yang diharapkan dan pengujian porositas mengacu pada standart ASTM C 373. Sampel yang akan diuji, dikeringkan di dalam oven dengan suhu $100^{\circ} \mathrm{C}$ selama 1 jam, kemudian ditimbang massanya dengan menggunakan neraca digital (mk). Sampel yang telah ditimbang kemudian direndam di dalam air selama 24 jam, bertujuan untuk mengoptimalkan penetrasi air terhadap sampel uji. Kemudian sampel yang telah direndam air selama 24 jam tersebut di lap terlebih dahulu dengan kain halus (tissue) kemudian ditimbang massanya menggunakan neraca digital (mb). Selanjutnya ditimbang massa kawat penggantung. Sampel yang telah di lap kemudian digantung di dalam air menggunakan kawat dan statif kemudian ditimbang massanya menggunakan neraca digital (mg). Dengan mengetahui besaran-besaran tersebut, maka porositas dapat ditentukan dengan menggunakan persamaan ${ }^{[3]}$ :

$$
P=\frac{m b-m o}{m b-(m g-m k)} x 100 \%
$$

dengan:

$P=$ porositas $(\%)$

$m o=$ massa awal sampel setelah kering $(\mathrm{g}), \quad m b=$ massa setelah direbus dalam air $(\mathrm{g})$

$m g=$ massa digantung dalam air $(\mathrm{g}), \quad m k=$ massa kawat penggantung sampel $(\mathrm{g})$

\section{Kuat Tekan (Compressive Strength)}

Kuat tekan suatu material didefinisikan sebagai kemampuan material dalam menahan beban atau gaya mekanis sampai terjadinya kegagalan (failure). Resin ini memiliki sifat kekuatan yang khas. Compressive strengthnya adalah 75 MPa (ASTM D 638). Secara umum bahan resin ini memiliki kekuatan rendah. Efek yang mempengaruhi kekuatan antara lain : komposisi, teknik pemprosesan, absorpsi air (Norman E, 1999).

Pengujian kekuatan tekan adalah mengukur kekuatan tekan bahan (sampel uji) terhadap tekanan mekanisnya. Alat yang digunakan untuk menguji kuat tekan adalah Universal Testing Machines (UTM) yang mengacu pada standard ASTM D 638. Sampel yang akan diuji diukur luas penampangnya dan diletakkan diantara tumpuan (lempengan) penekan. Sebelum pengujian berlangsung, alat terlebih dahulu dikalibrasi dengan jarum penunjuk tepat pada angka nol. Kemudian dihidupkan alat, kemudian dicatat angka yang ditunjukkan oleh pengukuran pada alat sebagai nilai $\mathrm{F}$ setelah sampel menjadi hancur. 
Dengan mengetahui besaran tersebut, maka nilai kekuatan tekan dapat ditentukan dengan menggunakan persamaan

$$
T=\frac{F}{A}
$$

dengan $F=$ gaya tekan/beban $(\mathrm{N})$

$A=$ cross section $\left(\mathrm{cm}^{2}\right)$

\section{Kuat Tarik (Tensile Strength)}

Pengujian kekuatan tarik adalah mengukur kekuatan tarik bahan (sampel uji) terhadap tekanan mekanisnya. Alat yang digunakan untuk menguji kuat tarik adalah Universal Testing Machines (UTM) yang mengacu pada standard ASTM D 638.

Sampel yang akan diuji diukur luas penampangnya dan diletakkan diantara tumpuan (lempengan) penarik. Sebelum pengujian berlangsung, alat terlebih dahulu dikalibrasi dengan jarum penunjuk tepat pada angka nol. Selanjutnya dihidupkan alat, kemudian dicatat angka yang ditunjukkan oleh pengukuran pada alat sebagai nilai $\mathrm{F}$ setelah sampel menjadi hancur.

\section{HASIL DAN PEMBAHASAN}

Dari data pengujian densitas dapat dibuat grafik seperti pada Gambar 2 dibawah ini:

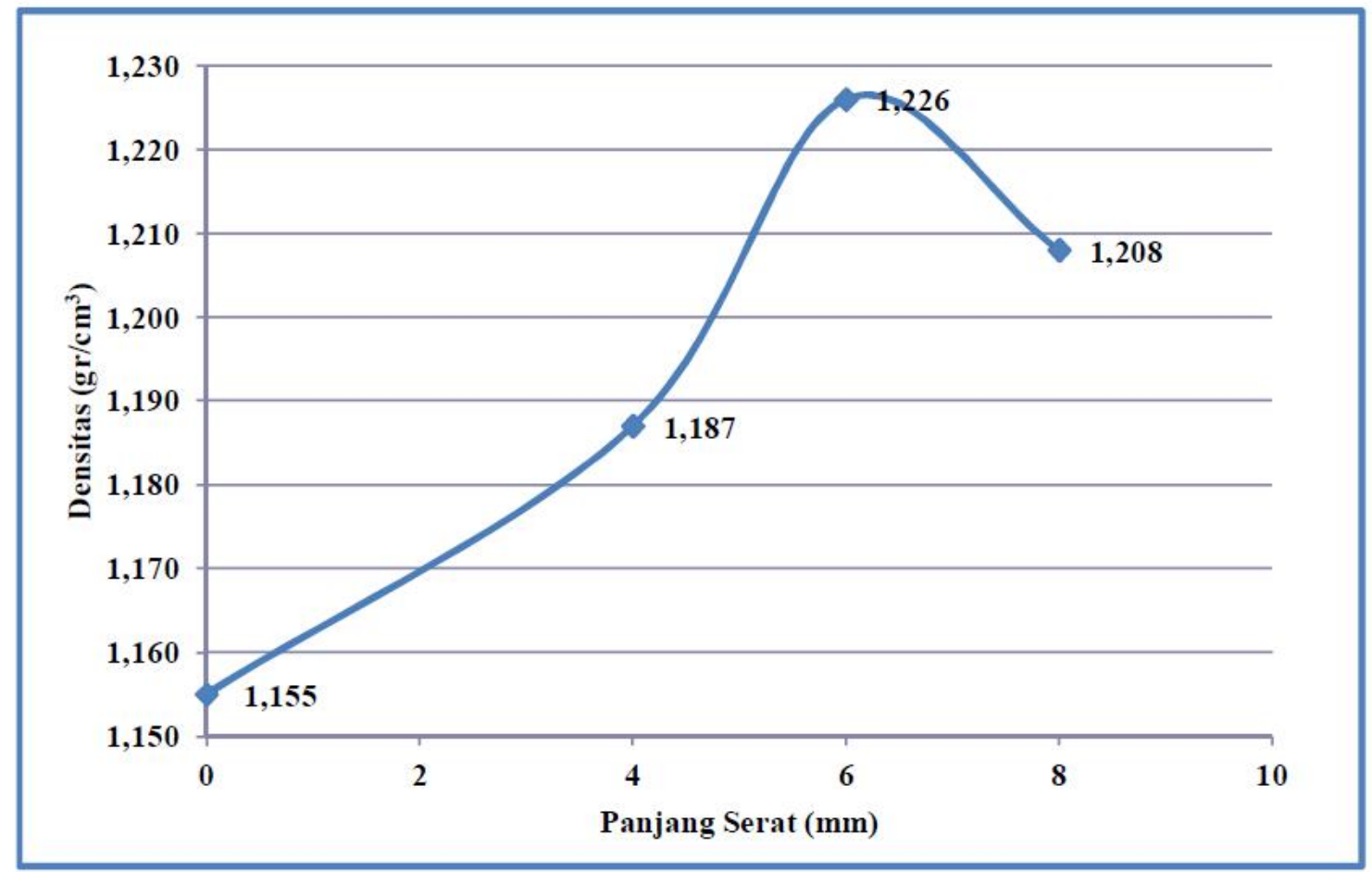

Gambar 2. (color online) Grafik hubungan densitas dan panjang serat

Dari Gambar 2 diatas terlihat bahwa densitas bertambah sampai panjang serat $6 \mathrm{~mm}$ dan menurun pada panjang $8 \mathrm{~mm}$. Ketika serat kaca berukuran $6 \mathrm{~mm}$, diasumsikan bahwa resin dapat membasahi seluruh bagian serat. Sebagai akibatnya diperoleh sampel dengan kerapatan tertinggi. Nilai densitas maksimum yang diperoleh sebesar $1,226 \mathrm{gr} / \mathrm{cm}^{3}$, nilai ini lebih besar 
dibanding kerapatan resin akrilik tanpa penguat $\left(0,995 \mathrm{gr} / \mathrm{cm}^{3}\right)^{[9]}$. Hasil ini sesuai dengan teori pencampuran, bahwa untuk bahan polimer yang diperkuat serat, akan terbentuk pori (hal yang tak mungkin dihindarkan). Dengan terbentuknya pori, makadensitas sampel akan menurun. Hal ini dapat diminimalisir dengan memperhatikan kehomogenan adonan setelah pengadukan. Nilai standard dapat dicapai dengan memperhatikan pencampuran material serata perbaikan dalam proses curing. Dari grafik diatas terlihat pula bahwa ketika ukuran serat ditambah sampai $8 \mathrm{~mm}$, serat tidak dapat membasahi seluruh bagian serat dikarenakan adanya tumpang tindih serat atau lipatan serat yang terjadi. Dengan demikian ukuran panjang serat $6 \mathrm{~mm}$ merupakan ukuran optimum untuk densitas bahan gigi tiruan.

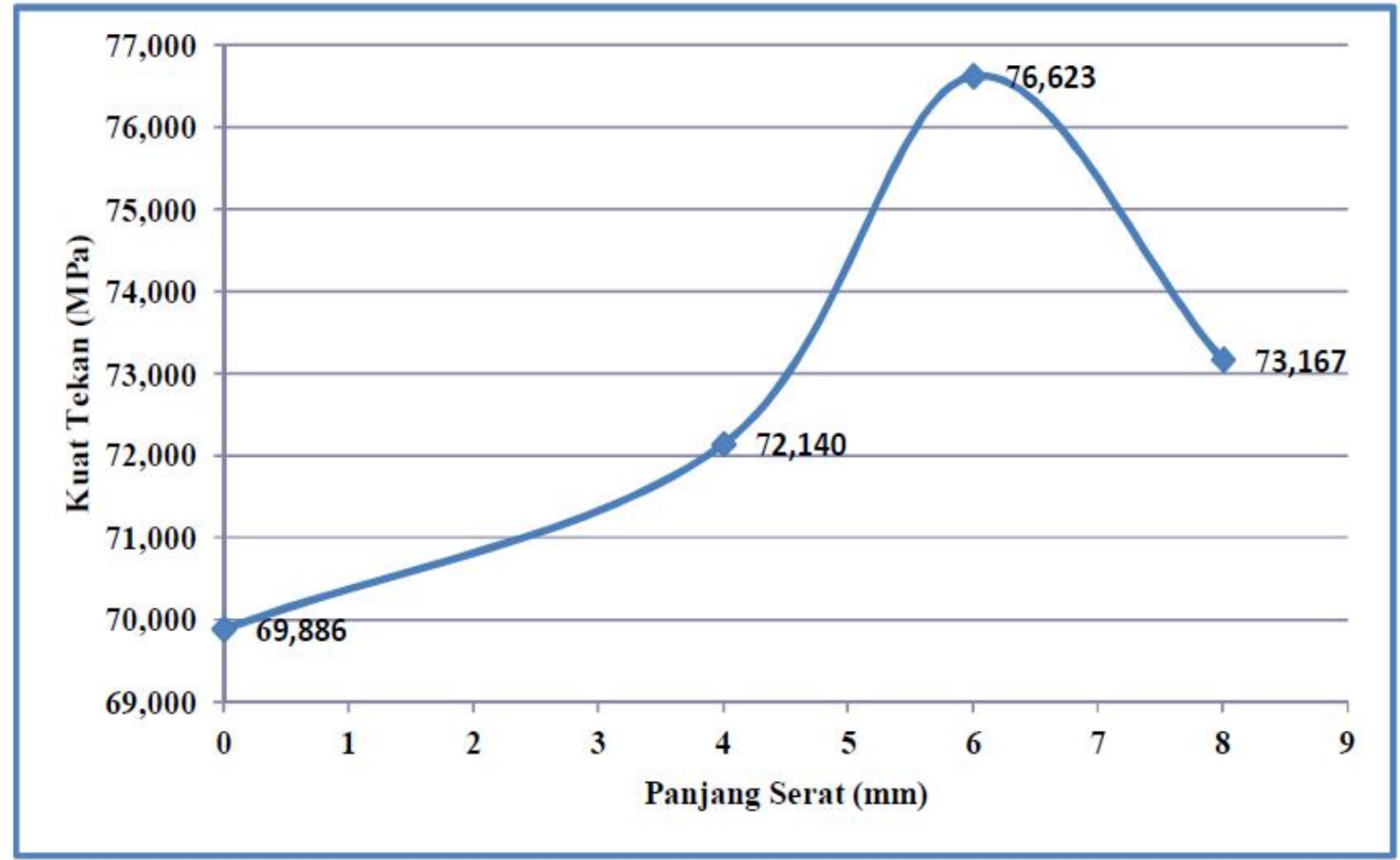

Gambar 3. (color online) Grafik hubungan Kekuatan tekan terhadap panjang serat kaca dengan resin akrilik polimerisasi panas.

Grafik 3 diatas menunjukkan kekuatan tekan menaik dengan penambahan panjang serat $(0 \mathrm{~mm}<\mathrm{x}<6 \mathrm{~mm})$. Akan tetapi kekuatan tekan menurun ketika panjang serat $8 \mathrm{~mm}$. Hal ini mengindikasikan bahwa panjang serat $6 \mathrm{~mm}$ merupakan panjang optimum untuk kekuatan tekan. Jika untuk aplikasi teknis, nilai kuat tekan resin akrilik $75 \mathrm{MPa}^{[9]}$, maka komposisi panjang serat $6 \mathrm{~mm}$ seperti Gambar 3 diatas sudah meningkatkan nilai kuat tekan sebesar $1,266 \mathrm{MPa}$ dan dapat direkomendasikan digunakan sebagai gigi tiruan. Penurunan nilai kuat tekan pada panjang serat $8 \mathrm{~mm}$ kemungkinan besar diakibatkan terjadinya penggumpalan sehingga jumlah pori bertambah. Hal ini dapat dikonfirmasi dengan menurunnya nilai densitas seperti pada grafik yang disajikan pada Gambar 2. 


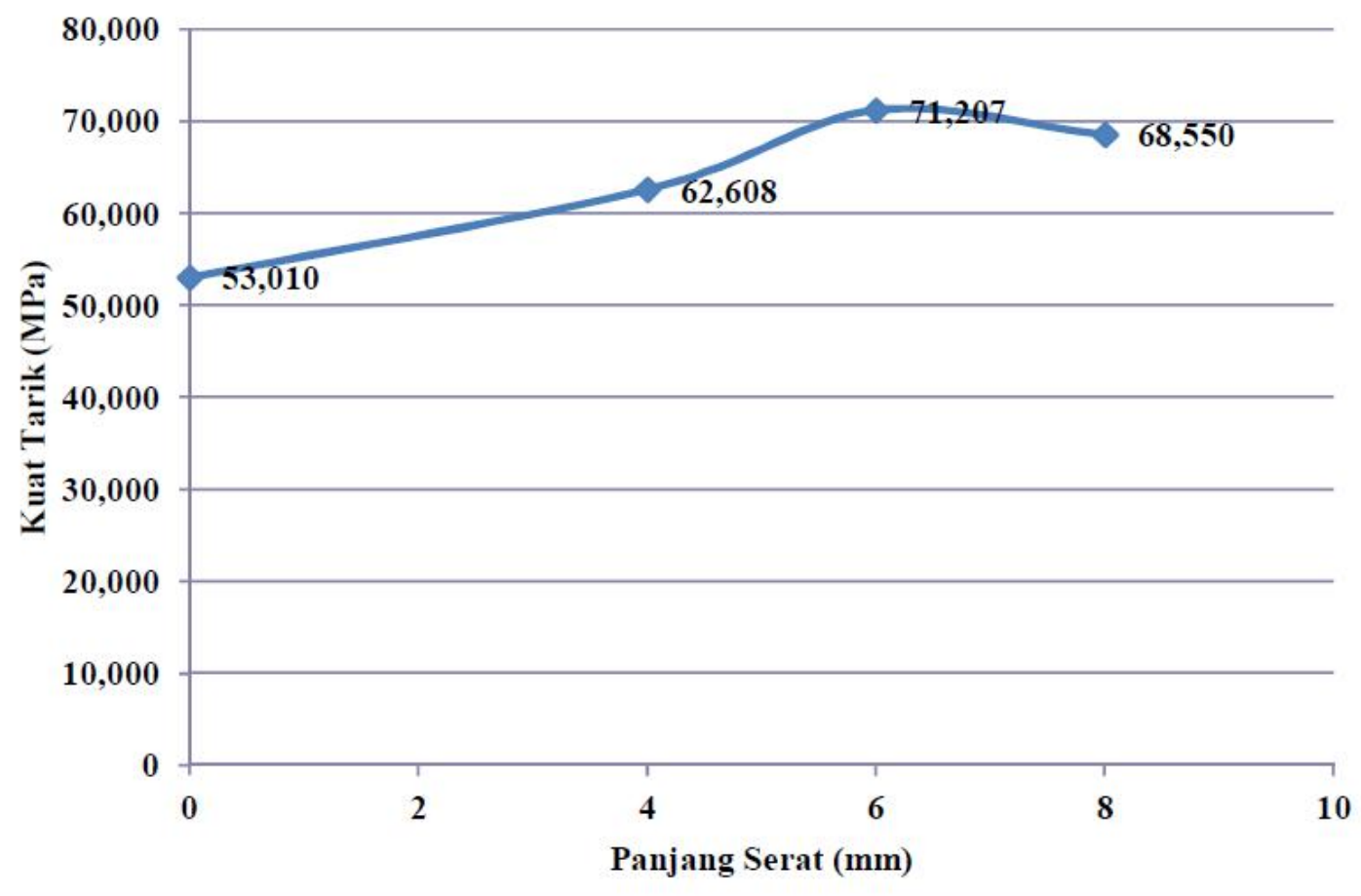

Gambar 4. (color online) Grafik hubungan antara kekuatan tarik terhadap panjang serat

Untuk aplikasi gigi tiruan, maka ukuran serat $6 \mathrm{~mm}$ adalah direkomendasikan. Karena pada ukuran ini, serat mentransfer beban secara maksimum. Jika dianggap beban diterima dan diteruskan pada ujung-ujung serat, maka seharusnya kekuatan tarik adalah maksimum juga. Hal ini ternyata konsisten dengan hasil pengujian kekuatan tarik seperti disajikan pada grafik Gambar 4 diatas. Dari Gambar 3 terlihat bahwa kuat tarik maksimum sekitar $71 \mathrm{MPa}$ dan telah meningkatkan nilai kuat tarik resin akrilik $(55 \mathrm{MPa})^{[9]}$.

\section{KESIMPULAN}

Penelitian tentang potensi serat gelas sebagai penguat telah berhasil dilakukan terhadap resin akrilik polimerisasi panas. Uji densitas menunjukkan adanya penurunan nilai densitas setelah penambahan serat gelas. Pengujian mekanis yang meliputi uji tarik dan uji tekan pada sampel yang diperkuat dengan serat gelas menunjukkan nilai yang lebih baik dibanding tanpa serat. Nilai optimum diperoleh ketika panjang serat $6 \mathrm{~mm}$, dan komposisi ini direkomendasikan dapat diaplikasikan untuk basis gigi tiruan. Namun demikian, masih diperlukan uji klinis lain (efek terhadap jaringan) untuk dapat mengaplikasikan serat gelas sebagai penguat.

\section{UCAPAN TERIMAKASIH}

Kami mengucapkan terimakasih kepada Ibu Prof. Haslinda. Z. Tamin, drg., M.Kes., Sp. Pros (K) sebagai koordinator dan manager unit UJI dental FKG USU dan Siti Wahyuni, drg selaku staf unit UJI dental FKG USU yang telah membantu penyiapan sampel dan pengujian bahan penelitian ini. 


\section{DAFTAR PUSTAKA}

1 Anusavice, Kenneth. J, Philips, 2003, Buku Ajar Ilmu Bahan Kedokteran Gigi, Trans, Johan Arif Budiman, Susi Puwoko, Lilian Juwono, eds. Edisi 10, EGC : Jakarta.

2 Chan, R. W, Hansen. P, Kramer. E. J, Material Science and Technology, Comprehensive Treatment vol 2A, Characterisation of material Part 1, Eric Lifshin : New York, 1993.

3 Craigh, R. G, Powers, J. M, Dental Materials Properties and Manipulations ed, Mosby: India, 2000.

4 El - Sheikh, A.M, Al - Zahrani, S.B, Cause of Densture Fracture: a survey, 2006.

5 Jagger, D. Harrison, Complete Dentures - Problem Solving, British Dental Associtation : London, 1999.

6 Lee S.I., Kim C.W., Lim Y.J., 2007, Strength of glass fiber reinforced PMMA resin and surface roughness changed after abrasion test. J Korean Acad Prostodont 2007 ; 45: 310-20.

7 Martanto, P, 1982, Ilmu Mahkota dan Jembatan (Fixed Partial Prosthodontics). Jilid 2, Alumni : Bandung

8 Polat T. N., Karacaer O., Water Sorbstion, Solubility and Dimensional Changes of Denture Base Polymer Reinforcedwith Short Glass Fibers, J. Biomate, 2003.

9 Polyzois, E. L, Andrepoulos, Acrylic Resin Denture Repair With Adhesive Resin and Metal Wires :Effects of Strength Parameter, 1996

10 Ramadhani H, Suci. 2011.Pembuatan dan Karakterisasi Bahan Gingiva Tiruan Berbasis Resin Akrilik dengan Penambahan Serat Kaca. Skripsi. Medan: Universitas Sumatera Utara

11 Stipho, H.D., Repair of acrylic resin base reinforced with glass fiber. J Prosthet Dent $1998 ; 80(5)$ : 546-50.

12 Tachir I.H., Kama J.D., Zortuk M. Flexural Properties of glass fiber reinforced acrylic resin polymers. J Aust Dent 2006 ; 51 : 52-56. 